\title{
The ability to enter into an avirulent viable but non-culturable (VBNC) form is widespread among Listeria monocytogenes isolates from salmon, patients and environment
}

\author{
Toril LindBäck ${ }^{1 *}$, Martin E. RottenBerg ${ }^{2}$, Sylvie M. Roche $^{3}$, Liv Marit RørVIK ${ }^{1}$ \\ ${ }^{1}$ Department of Food Safety and Infection Biology, Norwegian School of Veterinary Science, \\ P.O. Box 8146 Dep., N-0033 Oslo, Norway \\ ${ }^{2}$ Microbiology \& Tumorbiology Center, Karolinska Institute, Stockholm, Sweden \\ ${ }^{3}$ INRA, UR 1282, Infectiologie Animale et Santé Publique, IFR136, Agents transmissibles et Infectiologie, \\ F-37380 Nouzilly, France
}

(Received 12 May 2009; accepted 30 September 2009)

\begin{abstract}
Media-based bacteriological testing will fail to detect non-culturable organisms and the risk of consuming viable but non-culturable (VBNC) Listeria monocytogenes is unknown. We have here studied whether L. monocytogenes obtained from seafoods, processing environment and clinical cases enter the VBNC state and assessed the virulence of the non-culturable forms of the bacteria. A number of 16 L. monocytogenes strains were starved in microcosm water at $4{ }^{\circ} \mathrm{C}$ until loss of culturability. Metabolic activity in the VBNC form was measured as ATP generation using a luciferase assay and membrane integrity was examined using the LIVE/DEAD BacLight assay. All tested L. monocytogenes strains entered the VBNC state after starvation in microcosm water. Ongoing mRNA synthesis of $h l y$ in VBNC L. monocytogenes cells re-incubated in culture medium indicated a potential virulence of these forms. Sodium pyruvate and replenishment of nutrient were used in attempts to resuscitate VBNC cells. However, VBNC L. monocytogenes were not resuscitated under these conditions. VBNC L. monocytogenes were tested for virulence in a cell plaque assay and by intraperitoneally inoculation in immunodeficient $\mathrm{RAG1}^{-/-}$ mice. Inoculation of VBNC L. monocytogenes in immunodeficient mice did not cause morbidity, and plaque assay on HT-29 cells in culture indicated that the VBNC cells were avirulent. The results indicate that the risk of non-culturable L. monocytogenes in foods, when the VBNC state is induced by starvation, is negligible.
\end{abstract}

Listeria monocytogenes / VBNC / ATP / mRNA

\section{INTRODUCTION}

The occurrence of Listeria monocytogenes in foods has been a growing concern over the last decades. The bacteria cause listeriosis, a rare but serious illness, especially for the risk groups; the elderly, unborn children and

\footnotetext{
*Corresponding author: toril.lindback@nvh.no
}

immunocompromised persons. In 2007, 0.3 cases per 100000 were reported in the EU states, with a mortality of $20 \%$ [2]. Several small outbreaks of listeriosis have been associated with seafood [11, 22, 23, 30], and some countries have zero tolerance for $L$. monocytogenes in imported fish. Producers of seafood products demand L. monocytogenes free raw material for further processing, and the surveillance of 
L. monocytogenes during seafood-processing is becoming increasingly important.

Viable but non-culturable (VBNC) bacteria have been described as organisms that fail to grow and develop colonies on routine bacteriological media, but which are to be considered alive because of their capability of metabolic activity [34]. A number of pathogens including Vibrio vulnificus [33], Legionella pneumophila [45], Salmonella typhi [16] and Campylobacter jejuni [46] have been described to enter the state of VBNC after exposure to different stress factors such as starvation, shifts in temperature, high $\mathrm{NaCl}$ concentration and visible light [36]. L. monocytogenes has been shown to enter the VBNC state in response to starvation and exposure to high $\mathrm{NaCl}$ concentrations $[6,8]$. However, the studies included only four culture collection strains, of which only two were able to enter the VBNC state after starvation in microcosm water.

ATP levels, declining rapidly in dead cells, have been reported to remain high in VBNC cells, thus presence of ATP is a good viability marker of cells in the VBNC state [9, 24, 27]. The LIVE/DEAD BacLight assay, utilizing a mixture of the stains SYTO 9 and propidium iodide to evaluate cell membrane integrity, has been used to confirm viability in non-cultural bacteria [1, 27, 37]. Detection of mRNA, due to its central role in cell metabolism and its very short half-life, has previously been used as a viability marker for several pathogens including Vibrio cholerae [4], Escherichia coli [43], L. monocytogenes [26] and Vibrio parahaemolyticus [18]. Since Listeriolysin O $(h l y)$ is an important virulence factor in L. monocytogenes, expression of $h l y$ in the VBNC state will indicate a virulence potential present in the bacteria in the VBNC state.

The ability of $L$. monocytogenes to enter the VBNC state is of concern since media-based bacteriological tests used in routine will fail to detect non-culturable organisms from the processing environments and the products, and the hazard risks of consuming VBNC L. monocytogenes is still unknown. VBNC L. monocytogenes in foods might theoretically be able to resuscitate and account for virulence. Most studies on resuscitation have been performed on Vibrio sp., where a simple temperature up-shift or supplementing media with $\mathrm{H}_{2} \mathrm{O}_{2}$ degrading compounds such as Na-pyruvate results in resuscitation $[31,33,35]$. VBNC L. monocytogenes cannot be resuscitated directly in culture medium $[8,20]$, nevertheless they have been shown to resuscitate under appropriate conditions such as in embryonated eggs [14].

To our knowledge, little is known about how VBNC L. monocytogenes may resuscitate in the human organism. In the present study, we sought to investigate whether $L$. monocytogenes isolated from salmon and salmon-processing environment and clinical isolates were able to enter the VBNC state during starvation, and if the VBNC forms were virulent towards immunodeficient mice and human colon adenocarcinoma cells in culture.

\section{MATERIALS AND METHODS}

\subsection{Bacterial strains and culture conditions}

Fourteen strains of $L$. monocytogenes comprising six clinical isolates, five strains isolated from salmon and three strains isolated from processing plants [42] were studied. In addition, the Scott A (Pasteur Institute Culture Collection, France) and the EGDe strain [32] were included. Unless otherwise stated, bacteria were cultured in Brain Heart Infusion broth (BHI) (Oxoid, Basingstoke, UK) at $32{ }^{\circ} \mathrm{C}$. Colony forming units (CFU) were determined by plating appropriate dilutions on $5 \%$ bovine blood in blood agar base (Oxoid), followed by incubation at $37^{\circ} \mathrm{C}$ for 24 or $48 \mathrm{~h}$.

\subsection{Starvation in microcosm water}

Overnight BHI cultures of L. monocytogenes were washed three times in microcosm water (filtrated, autoclaved MQ water adjusted to $\mathrm{pH}$ 6.0) [41], and diluted to $5 \times 10^{7}$ organisms $/ \mathrm{mL}$ in $100 \mathrm{~mL}$ microcosm water in $250 \mathrm{~mL}$ flasks. The flasks were incubated at $4{ }^{\circ} \mathrm{C}$ with gentle shaking at $100 \mathrm{rpm}$. At inoculation and each week samples from the flasks were plated on blood agar for determination of $\mathrm{CFU}$. The plates were incubated at $37{ }^{\circ} \mathrm{C}$ for $48 \mathrm{~h}$. When no $\mathrm{CFU}$ were detected in $1 \mathrm{~mL}$ microcosm water, the organisms were examined for metabolic activity (ATP generation), damage to membranes (LIVE/DEAD Bac Light $^{\mathrm{TM}}$ viability 
staining) and accumulation of hly mRNA. The flasks were kept at $4{ }^{\circ} \mathrm{C}$ for 12 months for further examinations.

\subsection{ATP assay}

In order to test for ATP generation, $3 \mathrm{~mL}$ of the L. monocytogenes in microcosm water was pelleted for $5 \mathrm{~min}$ at $10000 \times \mathrm{g}$, and re-suspended in $220 \mu \mathrm{L}$ BHI. The samples were divided in two, and ATP was quantified in half of the sample immediately while the other half was incubated at $32{ }^{\circ} \mathrm{C}$ for $1 \mathrm{~h}$ before ATP quantification. ATP was quantified using the BacTiter-Glo Microbial Cell Viability assay kit (Promega, Madison, WI, USA) where $100 \mu \mathrm{L}$ sample was mixed with $100 \mu \mathrm{L}$ luciferase reagent and incubated for $5 \mathrm{~min}$ at room temperature. Luminescence (relative light units (RLU)) was recorded by a GloMax Integrated Luminescence System (Promega). The remaining $10 \mu \mathrm{L}$ of each sample was plated on blood agar to exclude that quantified ATP was generated by a limited number of cells that have not lost culturability. Previous experiments had shown a detection limit of $1 \times 10^{3}$ culturable $L$. monocytogenes cells by the BacTiter-Glo Microbial Cell Viability assay kit ${ }^{1}$, thus plating of $10 \mu \mathrm{L}$ would reveal culturable cells above the detection limit. ATP was quantified in BHI without VBNC cells as negative control. Each strain was tested in at least three experiments. An ATP standard curve was used for convertion of RLU values into ATP concentration (Roche Diagnostics, Mannheim, Germany).

Four randomly chosen strains (L839, L1069, L1372 and L2842) were grown to stationary phase, and diluted samples from the cultures were tested for ATP content, and plated on blood agar for determination of CFU. A curve was created by plotting ATP concentration against CFU, to estimate the number of $L$. monocytogenes cells corresponding to a known ATP concentration.

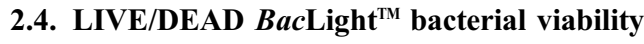 fluorescence microscopy}

Viability of non-culturable L. monocytogenes was examined using the LIVE/DEAD Bac Light $^{\mathrm{TM}}$ bacteria viability kit L-7007 (Molecular Probes, Eugene, OR, USA) according to the manufacturer's directions, and visualized with an Olympus IX81 inverted fluorescence microscope. The LIVE/DEAD BacLight ${ }^{\mathrm{TM}}$ assay is based on cell membrane integrity. The fluorescent SYTO 9 stain viable bacteria cells with intact

\footnotetext{
${ }^{1}$ Lindbäck T., unpublished results.
}

membranes green, while propidium iodide stains dead organisms with compromised membranes red. For each of the 16 tested strains, viable bacteria were observed in five random fields in each of two independent experiments from the same VBNC culture.

\subsection{Transcriptional analysis by reverse transcriptase PCR (RT-PCR)}

To demonstrate de novo mRNA synthesis of hly in VBNC L. monocytogenes, VBNC cells were incubated in BHI with and without rifampicin (SigmaAldrich), which inhibits mRNA synthesis. Five mL of VBNC solution was spun down at $10000 \times g$ for $5 \mathrm{~min}$, re-suspended in BHI with $10 \mu \mathrm{g} / \mathrm{mL}$ rifampicin (Sigma-Aldrich) and incubated at $32{ }^{\circ} \mathrm{C}$ for 2-10 h. The RNeasy Mini Kit (Qiagen, Hilden, Germany) was used for isolation of total RNA. The cDNA synthesis was performed using $0.5 \mu \mathrm{g}$ of DNase treated RNA; $0.2 \mu \mathrm{M}$ reverse hly primer, $1 \mathrm{mM}$ dNTP mix; $10 \mathrm{mM}$ DTT, $1 \times$ First Strand Synthesis Buffer (Invitrogen, Carlsbad, CA, USA) and $200 \mathrm{U}$ SuperScript III Reverse Transcriptase (Invitrogen), and incubated at $55^{\circ} \mathrm{C}$ for $60 \mathrm{~min}$. RNA was incubated in cDNA synthesis reaction buffer without reverse transcriptase to serve as a control for DNA contamination. Eight $\mu \mathrm{L}$ of the RT reaction was used in the following PCR amplification using 2 U DyNAzyme (Finnzymes Oy, Espoo, Finland) under following conditions; $94{ }^{\circ} \mathrm{C}$ for $4 \mathrm{~min}$ followed by a temperature cycling routine of denaturation at $94{ }^{\circ} \mathrm{C}$ for $1 \mathrm{~min}$, annealing at $52{ }^{\circ} \mathrm{C}$ for $1 \mathrm{~min}$ and extension at $72{ }^{\circ} \mathrm{C}$ for $1 \mathrm{~min}$. After 36 cycles a final extension at $72{ }^{\circ} \mathrm{C}$ for 5 min was performed and the tubes were cooled to $4{ }^{\circ} \mathrm{C}$. The primers used in the cDNA synthesis and the PCR reactions were hly forward (5'-ATTTTCCCTTCA CTGATTGC- $3^{\prime}$ ) and $h l y$ reverse (5'-CACTCAGCA TTGATTTGCCA-3') [17].

\subsection{Resuscitation by replenishment of nutrition}

Attempts to resuscitate the VBNC L. monocytogenes cells by replenishment of nutrients were done at $12{ }^{\circ} \mathrm{C}$ and $32{ }^{\circ} \mathrm{C}$ on 4 strains; Scott A (reference strain), L839 (salmon), L2842 (smoked salmon) and L3365 (clinical isolate). Erlenmeyer flasks containing three different concentrations of BHI medium $(0.1 \%, 1 \%$ and $10 \%$ of the concentration recommended by manufacturer) were incubated at the two different temperatures for each strain. Five $\mathrm{mL}$ diluted BHI medium was inoculated with $100 \mu \mathrm{L}$ each from the flasks with non-culturable $L$. monocytogenes strains, and incubated for 3 days at $12{ }^{\circ} \mathrm{C}$ and 
$32{ }^{\circ} \mathrm{C}$. After 3 days, samples of $100 \mu \mathrm{L}$ were plated on blood agar. The concentration of $\mathrm{BHI}$ in the flasks was then increased to $1 \%, 10 \%$ and $50 \%$, respectively. The flasks were further incubated for 3 days and samples of $100 \mu \mathrm{L}$ were plated on blood agar. A third sample was plated on blood agar after 9 days of incubation. The blood agar plates were incubated overnight at $32{ }^{\circ} \mathrm{C}$. The experiment was performed twice.

\subsection{Resuscitation with Na-pyruvate}

$\mathrm{H}_{2} \mathrm{O}_{2}$-degrading agents such as sodium pyruvate are previously shown to facilitate resuscitation [47] of VBNC organisms. Samples of $0.1 \mathrm{~mL}$ microcosms with VNBC L. monocytogenes cells were plated on BHI agar with $0.1 \%$ sodium pyruvate. Plates were checked for colonies after 24 and $48 \mathrm{~h}$ incubation.

\subsection{Plaque-forming cell assay}

The virulence of L. monocytogenes strains and their VBNC forms was estimated by a plaque-forming assay [40]. The virulent strain EGDe BUG1600 (Pasteur Institute culture Collection, France) was used as control. Human colon adenocarcinoma cell line HT-29 (ECACC N ${ }^{\circ} 85061109$, Salisbury, UK) was used between passages 86 and 95 . Cells were grown in $75-\mathrm{cm}^{2}$ plastic tissue culture flasks (Falcon, VWR) in Dulbecco's Modified Eagle Medium with $4.5 \mathrm{~g} / \mathrm{L}$ glucose (DMEM; GIBCO, Invitrogen) supplemented with $10 \%(\mathrm{v} / \mathrm{v})$ foetal calf serum (PAA) and $2 \mathrm{mM}$ L-glutamine (PAA). Antibiotics (100 IU/ $\mathrm{mL}$ penicillin, $100 \mu \mathrm{g} / \mathrm{mL}$ streptomycin (PAA)) were routinely added to the culture medium during maintenance of the cells, but not for the virulence assays. Cells were maintained in culture in a humidified incubator (NuAire DH Autoflow, MN, USA) at $37{ }^{\circ} \mathrm{C}$ under $5 \%(\mathrm{v} / \mathrm{v}) \mathrm{CO}_{2}$. Confluent HT-29 cell monolayers were cultured in DMEM supplemented with antibiotics in 96-well tissue culture plates for 4 or 5 days (Falcon, VWR) after inoculum of $3.2 \times 10^{4}$ cells or $2.4 \times 10^{4}$ cells in $100 \mu \mathrm{L}$ culture medium per well, respectively. One day before infection, cells were incubated in culture medium without antibiotics. Numbers of $10^{2}$ to $10^{7} \mathrm{~L}$. monocytogenes cells from an overnight BHI culture at $37^{\circ} \mathrm{C}$ or $10^{7}$ VBNC $L$. monocytogenes cells were added to each well of the monolayers. After $2 \mathrm{~h}$ at $37^{\circ} \mathrm{C}$, the extracellular bacteria were killed by incubation with $100 \mu \mathrm{g} / \mathrm{mL}$ gentamicin for $1 \mathrm{~h} 30 \mathrm{~min}$. The HT-29 cell monolayers were then overlaid with medium containing $0.8 \%$ SeaPlaque ${ }^{\circledR}$ GTG $^{\circledR}$ Agarose (Lonza, Rockland, ME,
USA) in the culture medium, supplemented with $10 \mu \mathrm{g} / \mathrm{mL}$ gentamicin, and further on with the latter culture medium without agarose. After overnight incubation, the wells were examined for formation of plaques using an inverted microscope. Duplicate wells were used and the experiment was repeated for each strain. Results were expressed as the number of plaques obtained for $7 \log L$. monocytogenes or VBNC L. monocytogenes per well. The mean of the results from all the experiments was used for determination the virulence of the EGDe control strain. Strains with values higher than the lower CI limit of the EGDe value were considered to be virulent.

\subsection{Injection of immunodeficient mice with VBNC L. monocytogenes Scott A}

L. monocytogenes Scott A starved to non-culturability for 12 weeks in microcosm water were concentrated by centrifugation to approximately $1 \times 10^{7}$ VBNC cells per $100 \mu \mathrm{L}$ (according to the LIVE/ DEAD BacLight ${ }^{\mathrm{TM}}$ assay) and injected intraperitoneally in PBS into four RAG1 ${ }^{-1-}$ mice. Mice were routinely weighted, sacrificed 2 weeks after injection and liver and spleen lysates prepared in 5 and $2 \mathrm{~mL} 0.1 \%$ triton containing PBS. One hundred $\mu \mathrm{L}$ of the lysates were then plated on BHI plates. The experiments in mice comply with the Karolinska Institute's regulations for care and use of laboratory animals.

\section{RESULTS}

\subsection{Starvation in microcosm water}

All tested strains of $L$. monocytogenes $(n=16)$ entered a non-culturable state after 5-12 weeks of incubation in microcosm water (mean $7.9 \pm 2.6 \mathrm{SD}$ ). Evolution of the culturable count of L. monocytogenes Scott A starved in microcosm water is shown in Figure 1. The decrease in CFU varied substantially among the strains, and no correlation was observed between the source of isolation and the rate of decrease in $\mathrm{CFU} / \mathrm{mL}$.

\subsection{Viability of non-culturable L. monocytogenes cells}

Non-culturable cells of all the 16 tested strains generated ATP, although they did not 


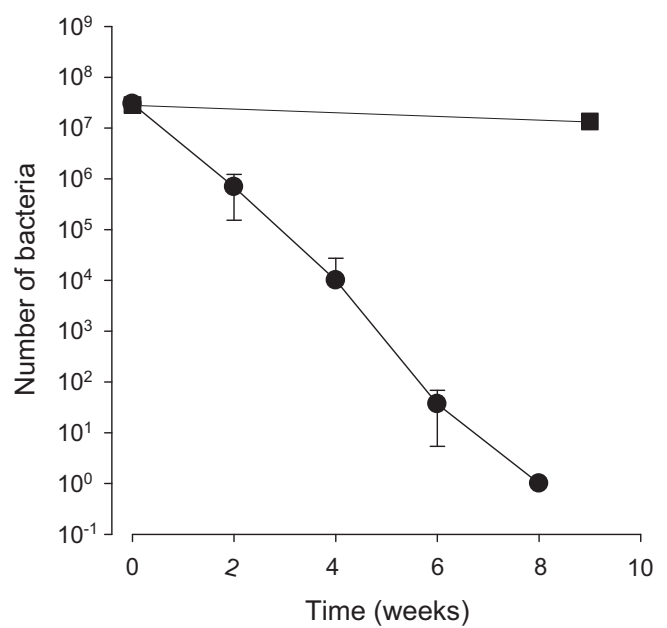

Figure 1. Evolution of the culturable count and the viable count ( $\mathbf{\square})$ of $L$. monocytogenes Scott $\mathrm{A}$ in microcosm water. The culturable cells were enumerated by spread plate counts, while viable counts were carried out using the LIVE/DEAD BacLight ${ }^{\mathrm{TM}}$ bacteria viability kit. The standard deviation is indicated.

grow on blood agar. Figure 2 shows the average ATP detected in non-culturable cells of the 16 tested strains after incubation in BHI for $1 \mathrm{~h}$ (3.4 $\pm 1.5 \mathrm{nM}$ SD). The ATP concentration remained at the approximately same level (2.3 $\pm 1.5 \mathrm{nM} \mathrm{SD}$ ) when measured after 3 days of incubation in BHI. The production of ATP indicated that the non-culturable cells were viable, and confirmed that they had entered the VBNC state. ATP generation measured in the strains maintained in microcosm water for 12 weeks, 6 and 12 months were similar, indicating that the VBNC L. monocytogenes were stable for at least one year in the microcosm water.

An ATP concentration of $3.4 \mathrm{nM}$ (the mean ATP concentration in the VBNC cells measured in $1.5 \mathrm{~mL}$ microcosm water) correspond to the ATP concentration in approximately $8 \times 10^{5}$ culturable L. monocytogenes cells. The total numbers of $L$. monocytogenes cells originally inoculated in the microcosm water were $5 \times 10^{7}$ cells $/ \mathrm{mL}$, thus $7.5 \times 10^{7}$ cells were tested for ATP content in each sample. This indicates that approximately $1 \%$ of the starved cells entered the VBNC state.

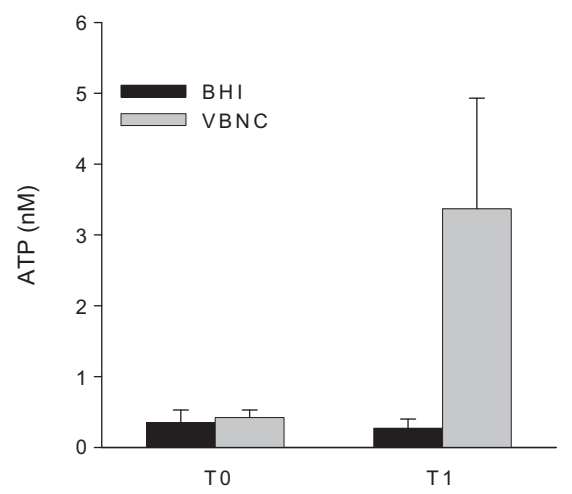

Figure 2. Average generation of ATP by $16 \mathrm{~L}$. monocytogenes strains in the VBNC state were monitored by measuring ATP concentration in the cells directly from microcosm water (T0) and after $1 \mathrm{~h}$ of incubation in BHI (T1). BHI as negative control showed no variation in ATP concentration. The standard deviation is indicated.

Despite the loss of culturability, LIVE/ DEAD BacLight ${ }^{\mathrm{TM}}$ assay of L. monocytogenes strains starved to non-culturability showed that $68 \pm 16 \%$ SD of the cells remained viable (average of the 16 tested strains). Figure 3 shows microscopic pictures of LIVE/DEAD BacLight ${ }^{\mathrm{TM}}$ assay of VBNC L. monocytogenes ScottA.

\subsection{Transcriptional analysis of $h l y$}

Transcripts of hly were detected in VBNC cells of all the 16 strains by RT-PCR. To confirm that detected hly mRNA was a result of ongoing transcription, VBNC L. monocytogenes were incubated in BHI containing rifampicin which inhibits de novo mRNA synthesis, thus degradation of present mRNA can be studied. The variation in degradation of hly transcript with time for four of the strains is shown in Figure 4. In two of the tested strains, Scott A and L839, no hly transcripts could be detected $8 \mathrm{~h}$ after incubation with rifampicin. For the EGDe strain and strain L1069 a weak RT-PCR product indicated small amounts of hly mRNA $10 \mathrm{~h}$ after incubation with rifampicin. 

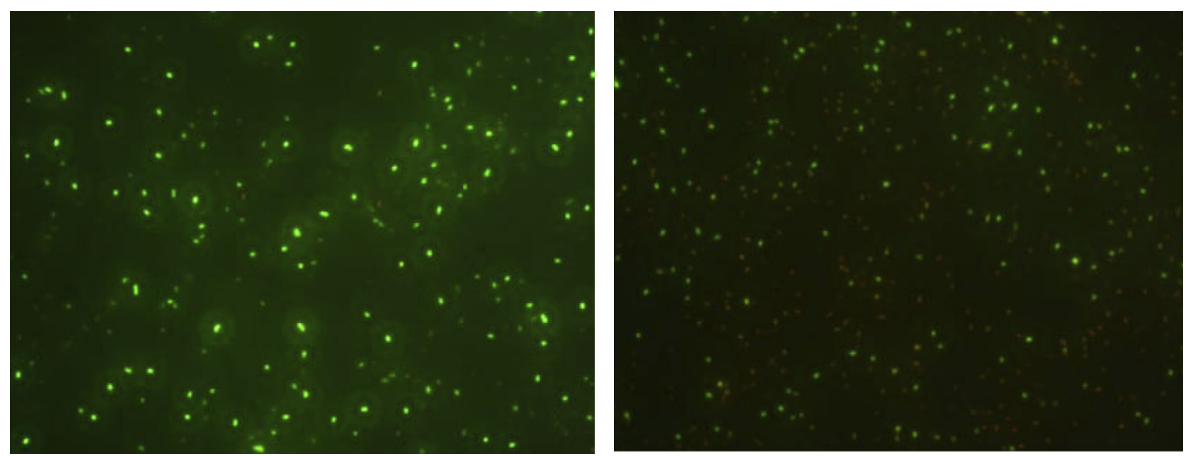

Figure 3. Microscopic pictures of LIVE/DEAD BacLight ${ }^{\mathrm{TM}}$ assay of VBNC L. monocytogenes Scott A. Left: directly from BHI culture, day 0 . Right: after 12 weeks in microcosm water. (A color version of this figure is available on line at www.vetres.org.)

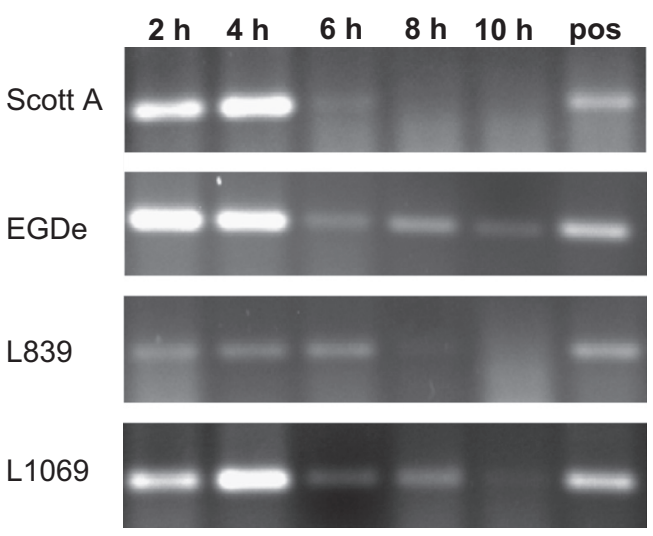

Figure 4. Expression of hly in five L. monocytogenes strains in the VBNC state after 2, 4, 6, 8 and $10 \mathrm{~h}$ incubation at $32{ }^{\circ} \mathrm{C}$ in $\mathrm{BHI}$ containing rifampicin detected by RT-PCR. The positive control (lane pos) was incubated in BHI without rifampicin for $10 \mathrm{~h}$. Experiments were performed at least twice.

\subsection{Resuscitation}

Attempts to resuscitate the VBNC L. monocytogenes cells by replenishment of nutrients were done at $12{ }^{\circ} \mathrm{C}$ and $32{ }^{\circ} \mathrm{C}$ on 4 of the 16 strains (L1069, L2842, L3365 and Scott A). None of the tested strains did resume growing in any concentration of BHI at any tested temperature. Neither plating VBNC cells directly on $\mathrm{BHI}$ plates containing $0.1 \%$ Na-pyruvate nor incubating VBNC cells in BHI cultures containing $0.1 \%$ Na-pyruvate, prior to plating, did result in resuscitation.

\subsection{Virulence in plaque-forming assay and immunodeficient mice}

All the 16 tested L. monocytogenes strains expressed virulence in the plaque-forming assay in their culturable form, except for L1338 $(4.28 \pm 0.24 \log )$. This strain was therefore tested in a mouse assay, and was shown to be virulent (data not shown). In contrast, none of the 16 tested VBNC L. monocytogenes expressed virulence (Tab. I).

VBNC L. monocytogenes Scott A were injected i.p. in $\mathrm{RAG}^{-{ }_{-}}$mice. Despite the high sensitivity of these $\mathrm{B}$ and $\mathrm{T}$ cell deficient animals to infection with $L$. monocytogenes, bacteria were not detected in spleen or livers from mice inoculated with $10^{\dagger} \mathrm{VBNC}$ L. monocytogenes.

\section{DISCUSSION}

In this study we show that all examined strains (16) of L. monocytogenes isolated from salmon, salmon-processing environment and patients, as well as two reference strains, entered the state of VBNC after starvation in microcosm water. We examined numerous 
Table I. Expression of virulence of 16 L. monocytogenes strains and their VBNC forms, by formation of plaques in the human adenocarcinoma cell line HT-29. The results are expressed as the number of plaques obtained for $7 \log$ CFU deposited per well.

\begin{tabular}{lccc}
\hline Strain & Source & $\begin{array}{c}\text { Virulence (mean log }+ \text { SD) } \\
\text { culturable strains }\end{array}$ & $\begin{array}{c}\text { Virulence (mean log + SD) } \\
\text { VBNC }\end{array}$ \\
\hline EGDe $^{\text {a }}$ (control) & Reference strain & $5.23 \pm 0.40$ & ND \\
Scott A & Reference strain & $6.38 \pm 0.03$ & 0 \\
EGDe $^{\text {b }}$ & Reference strain & $5.18 \pm 0.11$ & 0 \\
L1069 & Patient & $5.75 \pm 0.34$ & 0 \\
L1371 & Patient & $5.18 \pm 0.27$ & 0 \\
L1372 & Patient & $6.70 \pm 0.13$ & 0 \\
L3365 & Patient & $6.18 \pm 0.47$ & 0 \\
L3368 & Patient & $5.35 \pm 0.23$ & 0 \\
L3371 & Patient & $5.66 \pm 0.14$ & 0 \\
L839 & Salmon & $5.44 \pm 0.37$ & 0 \\
L1272 & Salmon & $5.81 \pm 0.26$ & 0 \\
L1338 & Salmon & $4.28 \pm 0.24$ & 0 \\
L2663 & Salmon & $4.98 \pm 0.16$ & 0 \\
L2735 & Salmon & $5.56 \pm 0.21$ & 0 \\
L1317 & Drainpipe & $4.88 \pm 0.27$ & 0 \\
L2842 & Salmon waste & $5.61 \pm 0.31$ & 0 \\
L1232 & Seawater & $5.88 \pm 0.13$ & \\
\hline
\end{tabular}

ND: Not done.

${ }^{\text {a }}$ Control used in the plaque cell test.

${ }^{\mathrm{b}}$ Used in the VBNC experiments.

${ }^{\mathrm{c}}$ Examined in a immunocompetent mouse assay and shown to be virulent.

strains from a wide selection of sources, and strains from different sources had the same ability to enter the VBNC state. All the tested strains entered the VBNC state, in contrast to results obtained by Besnard et al. [7, 8] where only 2 out of 4 culture collection L. monocytogenes strains entered the VBNC state after starvation. The difference in results may be due the use of environmental and patient isolates instead of laboratory reference strains, and the fact that the VBNC state was induced by starvation at different temperatures.

The time taken to reach the VBNC state broadly is in agreement with other studies, spanning between 5 and 12 weeks before no CFU could be detected in $1 \mathrm{~mL}$ microcosm. It lapsed 2, 4 and 6 weeks, respectively for Enterococcus faecalis, Edwardsiella tarda and Aeromonas hydrophila to become non-culturable in microcosm water at $4{ }^{\circ} \mathrm{C}[21,29,47]$, however, only a few strains were examined in each of those studies.
ATP quantification, LIVE/DEAD BacLight viable counts and mRNA transcription are included in this study to demonstrate viability in the non-culturable L. monocytogenes strains. ATP measurements has previously been used as a viability marker $[9,24,27]$, and RT-PCR have been used for investigating viability and potential virulence in VBNC $V$. parahaemolyticus, VBNC Enterococcus faecalis and VBNC $V$. vulnificus $[18,25,28]$. The so far most common used technique to confirm the VBNC state is the microscopic method using intracellular hydrolysis of CTC (5-cyano-2,3-ditolyl tetrazolium chloride) into an insoluble fluorescent salt by enzymes in the respiratory chain, and LIVE/ DEAD BacLight viable counts are reported to be comparable to results obtained with the CTC staining assay [10].

When ATP in the VBNC cells was measured after incubation in $\mathrm{BHI}$ for 3 days the concentration remained at the same level as for $1 \mathrm{~h}$ (Fig. 2), although the $\mathrm{VBNC}$ did not regain 
the ability to divide and grow on blood agar. This is consistent with results reported previously; L. monocytogenes cannot be resuscitated in rich medium such as BHI $[8,20]$, although the metabolic activity seems to be maintained. When L. monocytogenes had entered the state of VBNC and the cells were maintained in microcosm water at $4{ }^{\circ} \mathrm{C}$, we observed that the VBNC cells were stable for at least 12 months, corresponding with the observation presented by Bunker et al. [12] that Pseudomonas fluorescens can remain in the VBNC state for over a year. According to the LIVE/DEAD BacLight assay, the number of viable cells after 12 weeks in microcosm water varied between the strains, from 45 to $90 \%$ (mean $68 \pm 16 \% \mathrm{SD}$ ).

Our estimation of the proportion of viable cells differed markedly with the two methods employed. If one assumes that the ATP concentration is equivalent in culturable cells and VBNC cells, then the amount of ATP generated by VBNC L. monocytogenes suggests that $1 \%$ of the starved cells had entered the VBNC state. If, however, the ATP concentration is higher in growing cells than in VBNC cells, the percentage of cells entering the state of VBNC will be correspondingly greater. Even so, this appears to be substantially lower than that predicted from the LIVE/DEAD BacLight assay (68\%).

RT-PCR is not a quantitative method and may not be ideal for detection of mRNA halflife, but the results comparing accumulation of transcripts in presence or absence of rifampicin indicated a very long half-life $(6-10 \mathrm{~h})$ in VBNC L. monocytogenes compared to the mRNA half-life in culturable cells $(2-4 \mathrm{~min})$ [5, 38, 39]. Using RT-PCR, Smith and Oliver concluded that detected mRNA in VBNC $V$. vulnificus was a result of de novo synthesis, with a half-life of $60 \mathrm{~min}$ [44]. The results shown in Figure 4 clearly indicate an effect of rifampicin in three of the strains, Scott A, L839 and L1069, indicating de novo mRNA synthesis in VBNC L. monocytogenes.

Ongoing transcription of hly described in the present study together with the fact that VBNC L. monocytogenes could be resuscitated in embryonated eggs in a previous study [14], suggest maintenance of potential virulence. However, in this study they appeared avirulent to immunodeficient RAG1 ${ }^{-/-}$mice and HT-29 cells in culture. This is supported by Cappelier et al. [13] finding that VBNC L. monocytogenes LO 28, ATCC 19115, CNL 895807 and Scott A, were negative for virulence in the HT-29 cell assay and in immunocompetent mice.

In this study we have tried to resuscitate the VBNC L. monocytogenes by gradually adaptation to nutrients at different temperatures attempting to emulate real life conditions. However, none of the tested strains regained the ability to grow and form colonies by gradual replenishment of nutrients. Neither did addition of the $\mathrm{H}_{2} \mathrm{O}_{2}$-degrading compound $\mathrm{Na}$-pyruvate facilitate resuscitation of the VBNC L. monocytogenes cells. This is in contrast to Vibrio ssp. [44, 48], Enterococci [29] and Citrobacter [19] that have been successfully resuscitated in culture medium. Campylobacter required animal models such as mice and embryonated eggs to regain culturability $[3,15]$. However, L. monocytogenes did neither resuscitate after injection in immunocompetent mice in the study by Cappelier et al. [13], nor in immunodeficient mice in the present study.

In conclusion, the entrance of L. monocytogenes into the VBNC state is of interest for the food industry since routine bacteriological testing will fail to detect non-culturable organisms in the processing environment and in the products. We found that L. monocytogenes isolated from salmon, salmon-processing environment and patients entered the VBNC state after starvation. Despite viability according to ATP generation, membrane integrity and hly de novo transcription, the VBNC cells were neither resuscitated by addition of the $\mathrm{H}_{2} \mathrm{O}_{2}$-degrading compound Na-pyruvate nor by a gradual adaptation to nutrients. In view of the fact that VBNC L. monocytogenes did not show virulence in immunodeficient mice and HT-29 cells in culture, we propose that VBNC L. monocytogenes induced by starvation are avirulent.

Acknowledgements. The study was supported by grant 169123-NKJ123 from the Norwegian Research Council. We thank Annette Fagerlund, Simon Hardy and Hannah Jørgensen for fruitful discussions and for critically reading the manuscript. 


\section{REFERENCES}

[1] Adams B.L., Bates T.C., Oliver J.D., Survival of Helicobacter pylori in a natural freshwater environment, Appl. Environ. Microbiol. (2003) 69:74627466 .

[2] Anonymous, The Community Summary Report on Trends and sources of zoonoses and zoonotic agents in the European Union in 2007, The EFSA Journal (2009) 223:136-158.

[3] Baffone W., Casaroli A., Citterio B., Pierfelici L., Campana R., Vittoria E., et al., Campylobacter jejuni loss of culturability in aqueous microcosms and ability to resuscitate in a mouse model, Int. J. Food Microbiol. (2006) 107:83-91.

[4] Bej A.K., Ng W.-Y., Morgan S., Jones D.D., Mahbubani M.H., Detection of viable Vibrio cholerae by reverse-transcriptase polymerase chain reaction (RT-PCR), Mol. Biotechnol. (1996) 5:1-10.

[5] Bernstein J.A., Khodursky A.B., Lin P.H., Lin-Chao S., Cohen S.N., Global analysis of mRNA decay and abundance in Escherichia coli at singlegene resolution using two-color fluorescent DNA microarrays, Proc. Natl. Acad. Sci. USA (2002) 99:9697-9702.

[6] Besnard V., Federighi M., Cappelier J.M., Development of a direct viable count procedure for the investigation of VBNC state in Listeria monocytogenes, Lett. Appl. Microbiol. (2000) 31:77-81.

[7] Besnard V., Federighi M., Cappelier J.-M., Evidence of viable but non-culturable state in Listeria monocytogenes by direct viable count and CTC-DAPI double staining, Food Microbiol. (2000) 17:697-704.

[8] Besnard V., Federighi M., Declerq E., Jugiau F., Cappelier J.-M., Environmental and physico-chemical factors induce VBNC state in Listeria monocytogenes, Vet. Res. (2002) 33:359-370.

[9] Beumer R.R., deVries J., Rombouts F.M., Campylobacter jejuni non-culturable coccoid cells, Int. J. Food Microbiol. (1992) 15:153-163.

[10] Boulos L., Prevost M., Barbeau B., Coallier J., Desjardins R., LIVE/DEAD BacLight : application of a new rapid staining method for direct enumeration of viable and total bacteria in drinking water, J. Microbiol. Methods (1999) 37:77-86.

[11] Brett M.S.Y., Short P., McLauchlin J., A small outbreak of listeriosis associated with smoked mussels, Int. J. Food Microbiol. (1998) 43:223-229.

[12] Bunker S.T., Bates T.C., Oliver J.D., Effects of temperature on detection of plasmid or chromosomally encoded gfp- and lux-labeled Pseudomonas fluorescens in soil, Environ. Biosafety Res. (2004) 3:83-90.

[13] Cappelier J.M., Besnard V., Roche S., Garrec N., Zundel E., Velge P., Federighi M., Avirulence of viable but non-culturable Listeria monocytogenes cells dem- onstrated by in vitro and in vivo models, Vet. Res. (2005) 36:589-599.

[14] Cappelier J.-M., Besnard V., Roche S.M., Velge P., Federighi M., Avirulent viable but non culturable cells of Listeria monocytogenes need the presence of an embryo to be recovered in egg yolk and regain virulence after recovery, Vet. Res. (2007) 38:573-583.

[15] Chaveerach P., ter Huurne A.A., Lipman L.J., van Knapen F., Survival and resuscitation of ten strains of Campylobacter jejuni and Campylobacter coli under acid conditions, Appl. Environ. Microbiol. (2003) 69:711-714.

[16] Cho J.C., Kim S.J., Viable, but non-culturable, state of a green fluorescence protein-tagged environmental isolate of Salmonella typhi in groundwater and pond water, FEMS Microbiol. Lett. (1999) 170:257-264.

[17] Cooray K.J., Nishibori T., Xiong H., Matsuyama T., Fujita M., Mitsuyama M., Detection of multiple virulence-associated genes of Listeria monocytogenes by PCR in artificially contaminated milk samples, Appl. Environ. Microbiol. (1994) 60:3023-3026.

[18] Coutard F., Pommepuy M., Loaec S., Hervio-Heath D., mRNA detection by reverse transcription-PCR for monitoring viability and potential virulence in pathogenic strain of Vibrio parahaemolyticus in viable but nonculturable state, J. Appl. Microbiol. (2005) 98:951-961.

[19] Dhiaf A., Bakhrouf A., Witzel K.P., Resuscitation of eleven-year VBNC Citrobacter, J. Water Health (2008) 6:565-568.

[20] Dreux N., Albagnac C., Federighi M., Carlin F., Morris C.E., Nguyen-The C., Viable but non-culturable Listeria monocytogenes on parsley leaves and absence of recovery to a culturable state, J. Appl. Microbiol. (2007) 103:1272-1281.

[21] Du M., Chen J., Zhang X., Li A., Li Y., Wang Y., Retention of virulence in a viable but nonculturable Edwardsiella tarda isolate, Appl. Environ. Microbiol. (2007) 73:1349-1354.

[22] Ericsson H., Eklöw A., Danielsson-Tham M.-L., Loncarevic S., Mentzing L.-O., Persson I., et al., An outbreak of listeriosis suspected to have been caused by rainbow trout, J. Clin. Microbiol. (1997) 35: 2904-2907.

[23] Farber J.M., Daley E.M., MacKie M.T., Limerick B., A small outbreak of listeriosis potentially linked to the consumption of imitation crab meat, Lett. Appl. Microbiol. (2000) 31:100-104.

[24] Federighi M., Tholozan J.L., Cappelier J.M., Tissier J.P., Jouve J.L., Evidence of non-coccoid viable but non-culturable Campylobacter jejuni cells in microcosm water by direct viable count, CTC-DAPI double staining, and scanning electron microscopy, Food Microbiol. (1998) 15:539-550.

[25] Fischer-Le Saux M., Hervio-Heath D., Loaec S., Colwell R.R., Pommepuy M., Detection of 
cytotoxin-hemolysin mRNA in nonculturable populations of environmental and clinical Vibrio vulnificus strains in artificial seawater, Appl. Environ. Microbiol. (2002) 68:5641-5646.

[26] Klein P.G., Juneja V.K., Sensitive detection of viable Listeria monocytogenes by reverse-transcription-PCR, Appl. Environ. Microbiol. (1997) 63: 4441-4448.

[27] Li J., Kolling G.L., Matthews K.R., Chikindas M.L., Cold and carbon dioxide used as multi-hurdle preservation do not induce appearance of viable but non-culturable Listeria monocytogenes, J. Appl. Microbiol. (2003) 94:48-53.

[28] Lleo M.M., Pierobon S., Tafi M.C., Signoretto C., Canepari P., mRNA detection by reverse transcription-PCR for monitoring viability over time in an Enterococcus faecalis viable but nonculturable population maintained in a laboratory microcosm, Appl. Environ. Microbiol. (2000) 66:4564-4567.

[29] Lleo M.M., Bonato B., Tafi M.C., Signoretto C., Boaretti M., Canepari P., Resuscitation rate in different enterococcal species in the viable but non-culturable state, J. Appl. Microbiol. (2001) 91:1095-1102.

[30] Miettinen M.K., Siitonen A., Heiskanen P., Haajanen H., Björkroth K.J., Korkeala H.J., Molecular epidemiology of an outbreak of febrile gastroenteritis caused by Listeria monocytogenes in cold-smoked rainbow trout, J. Clin. Microbiol. (1999) 37: 2358-2360.

[31] Mizunoe Y., Wai S.N., Ishikawa T., Takade A., Yoshida S., Resuscitation of viable but nonculturable cells of Vibrio parahaemolyticus induced at low temperature under starvation, FEMS Microbiol. Lett. (2000) 186:115-120.

[32] Murray E.G.D., Webb R.A., Swann M.B.R., A disease of rabit characterised by a large mononuclear leucocytosis, caused by a hitherto undescribed bacillus; Bacterium monocytogenes (n.sp.), J. Pathol. Bacteriol. (1926) 29:407-439.

[33] Oliver J.D., Hite D., McDougald D., Andon N.L., Simpson L.M., Entry into, and resuscitation from, the viable but nonculturable state be Vibrio vulnificus in an estuarine environment, Appl. Environ. Microbiol. (1995) 61:2624-2630.

[34] Oliver J.D., The public health significance of viable but nonculturable bacteria, in: Colwell R.R., Grimes D.J. (Eds.), Nonculturable Microorganisms in the Environment, American Society for Microbiology Press, Washington, DC, 2000, pp. 277-299.

[35] Oliver J.D., Bockian R., In vivo resuscitation, and virulence towards mice, of viable but nonculturable cells of Vibrio vulnificus, Appl. Environ. Microbiol. (2005) 61:2620-2623.

[36] Oliver J.D., The viable but nonculturable state in bacteria, J. Microbiol. (2006) 43:93-100.

[37] Ordax M., Marco-Noales E., Lopez M.M., Biosca E.G., Survival strategy of Erwinia amylovora against copper: induction of the viable-but-nonculturable state, Appl. Environ. Microbiol. (2006) 72:34823488 .

[38] Pease A.J., Roa B.R., Luo W., Winkler M.E., Positive growth rate-dependent regulation of the $p d x A$, $\operatorname{ksg} A$, and $p d x B$ genes of Escherichia coli K-12, J. Bacteriol. (2002) 184:1359-1369.

[39] Rieu A., Weidmann S., Garmyn D., Piveteau P., Guzzo J., agr System of Listeria monocytogenes EGDe: Role in adherence and differential expression pattern, Appl. Environ. Microbiol. (2007) 73:61256133.

[40] Roche S.M., Velge P., Bottreau E., Durier C., Marquet-van der Mee N., Pardon P., Assessment of the virulence of Listeria monocytogenes: agreement between a plaque-forming assay with HT-29 cells and infection of immunocompetent mice, Int. J. Food Microbiol. (2001) 68:33-44.

[41] Rollins D.M., Colwell R.R., Viable but nonculturable stage of Campylobacter jejuni and its role in survival in the natural aquatic environment, Appl. Environ. Microbiol. (1986) 52:531-538.

[42] Rørvik L.M., AAse B., Alvestad T., Caugant D.A., Molecular epidemiological survey of Listeria monocytogenes in seafoods and seafood-processing plants, Appl. Environ. Microbiol. (2000) 66: 4779-4784.

[43] Sheridan G.E.C., Masters C.I., Shallcross J.A., Mackey B.M., Detection of mRNA by reverse transcription-PCR as an indicator of viability in Escherichia coli cells, Appl. Environ. Microbiol. (1998) 64:1313-1318.

[44] Smith B., Oliver J.D., In situ and in vitro gene expression by Vibrio vulnificus during entry into, persistence within, and resuscitation from the viable but nonculturable state, Appl. Environ. Microbiol. (2006) 72:1445-1451.

[45] Steinert M., Emody L., Amann R., Hacker J., Resuscitation of viable but nonculturable Legionella pneumophila Philadelphia JR32 by Acanthamoeba castellanii, Appl. Environ. Microbiol. (1997) 63:2047-2053.

[46] Tholozan J.L., Cappelier J.-M., Tissier J.P., Delattre G., Federighi M., Physiological characterization of viable-but-nonculturable Campylobacter jejuni cells, Appl. Environ. Microbiol. (1999) 65 1110-1116.

[47] Wai S., Mizunoe Y., Takade A., Yoshida S., A comparison of solid and liquid media for resuscitation of starvation- and low-temperature-induced nonculturable cells of Aeromonas hydrophila, Arch. Microbiol. (2000) 173:307-310.

[48] Wong H.C., Wang P., Chen S.Y., Chiu S.W., Resuscitation of viable but non-culturable Vibrio parahaemolyticus in a minimum salt medium, FEMS Microbiol. Lett. (2004) 233:269-275. 